\title{
揚水循環併用バイオスパージングエ法による ベンゼン污染帯水層の浄化特性
}

\author{
桐山 久 1 高畑 陽 $2 \cdot$ 大石 $\quad$ 雅也 3 ・有山 元茂 4 ・今村 $\quad$ 聡 5 佐藤 健 6

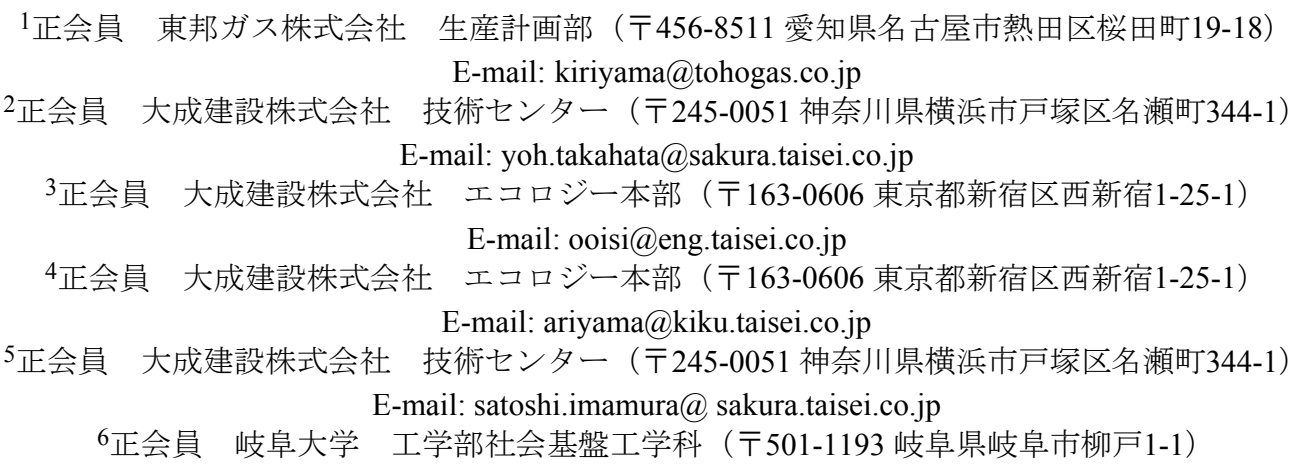 \\ E-mail: tsat@gifu-u.ac.jp.
}

\begin{abstract}
バイオスパージング工法は，ベンゼンで污染された深部の土壤を浄化する場合に有効な浄化技術である. 本工法は，帯水層中に空気を供給することにより， ベンゼンの気化による物理的除去と微生物分解の促進 を期待できる。しかし，これまで栄養塩の効率的な供給方法が存在しなかったため，継続的な微生物分解 効果を得ることが困難であった。そこで，筆者らは栄養塩を地盤に効率的に供給できる揚水循環併用バイ オスパージング工法を開発した。実污染サイトにおいて実証試験を行い，当工法によるベンゼンの浄化効 果と空気や栄養塩の供給能力について検討し, 従来工法と比較した優位性を確認した. また, 本試験の結 果に基づき，当工法の井戸配置や浄化期間予測についての設計手法を確立した.
\end{abstract}

Key Words : bioremediation, benzene, flushing, biosparging, in- situ remediation

\section{1. はじめに}

近年，土壤が污染された土地に対して，土壌污染 対策法や各地方自治体における土㙵污染に関する条 例の施行により法規制が強化されている。 また，不 動産の鑑定評価においても，土壌污染に関する初期 的な調查が義務付けられている。このように社会情 勢が変化する中, 工場跡地などにおいて土㙵污染の 調査を行い，污染の判明に伴って污染土畩を浄化す る機会が増加している1),2),3).

污染土袞の浄化方法として, 污染深度が比較的浅 い場合には，污染土壌の掘削処理工法が広く用いら れている。一方，污染物質が深部まで広がった污染 拡散域に対しては，コストを低く抑えることが可能 であることなどの理由から，原位置浄化工法が採用 されるケースが増えている(1),5), 6,7), 8),99.

ベンゼンは比較的水溶性が高い揮発性有機化合物 であり，その発ガン性のため ${ }^{10)}$ ，土壌污染対策法の
第一種特定有害物質に指定されている. ベンゼンは 好気性細菌により分解されるため $\left.{ }^{11)}, 12\right)$, 空気供給井 戸（スパージング井戸）を用いてベンゼンで污染さ れた帯水層に酸素（空気）を供給することにより， ベンゼンの微生物分解を促進できることが知られて いる4). 本技術はバイオスパージング工法と呼ばれ ており，ベンゼンの気化による物理的浄化効果も併 せて期待できるため, ベンゼンで污染された帯水層 の浄化に適した原位置浄化技術と考えられてい $3^{13), 14), 15), 16), 17), 18)}$.

一方, 微生物分解効果を長期的に維持するために は, 酸素と共に微生物の増殖に不足してくる窒素や リンなどの栄養塩を供給する必要がある。栄養塩の 地盤への供給方法として, 栄養塩を溶解させた栄養 水を別途設置した注水井戸から帯水層に供給寸る方 法が用いられることがある ${ }^{19)}$. しかしながら，注水 井戸を利用して栄養水を自然浸透させる方法は, 注 入効率が低く, 井戸の目詰まり（バイオファウリン 
グ）が生じやすいこと4)などの課題があり，特に透 水性の比較的低い地盤に対する栄養塩の供給は難し いと考えられてきた.

筆者らは，栄養塩を効率的に地盤に供給する手段 として，空気と液体を同時に供給可能なスパージン グ井戸（以下，注水スパージング井戸） と揚水井戸 を用い，地盤に設置する井戸本数を低減可能な揚水 循環併用バイオスパージング工法（以下，注水バイ オスパージング工法）を開発した（図-1）。

本工法は，注水施設をスパージング井戸に付設す ることで，空気と液体を 1 本のスパージング井戸か ら連続的に帯水層へ供給できるため, 注水井戸を別 途作成する必要がない，栄養水はスパージング井戸 の吐出圧を利用して地盤内に供給される。また，注 水に用いる液体は, 揚水した污染地下水を処理して 再利用し地下水を循環させることにより，微生物の 増殖を妨げる代謝産物などの蓄積を防ぎ，微生物の 分解活性を長期的に維持できる.

筆者らは，石炭ガス製造工場跡地内のベンゼン污 染帯水層を対象として実証試験を実施し, 注水バイ オスパージング工法によるベンゼンの浄化効果と注 水スパージング井戸の空気および栄養塩の供給能力 について検討した，本試験結果から，本工法の従来 工法と比較した優位性を確認するとともに，最適な 浄化井戸の配置に関寸る評価方法や浄化期間の予測 に関する設計手法についての妥当性を検証した.

\section{2. 実証試験サイトの概要}

注水バイオスパージング工法の効果を検証するた めの実証試験は，石炭ガス製造工場跡地内のベンゼ ンで污染された不圧（第一）帯水層を浄化対象とし て実施した。試験域の地下水位は約 G.L.-1m であり, G.L.-1〜 -2m には高濃度のベンゼンを含む油混じり の埋土（污染源）が存在した。図-2 に実証試験サイ トの土質性状，任意の 6 地点で観測したベンゼン溶 出量および多環芳香族炭化水素（PAHs）含有量の 平均值を示寸。污染源下部の G.L.-2〜-6m のシルト 混じり細砂中にも污染源から拡散したと考えられる 比較的高濃度のベンゼンが存在しており，本試験で は G.L.-1〜-6m の帯水層に存在するベンゼンを浄化 対象として試験を実施した。

污染の拡散を防止するため，図-3に示すように鋼 矢板を $10 \mathrm{~m}$ 角の範囲で不透水層（G.L.-8.5m）まで打 設して囲い込み，鋼矢板継手部から空気や水が漏洩 しないように防水対策を施した。また，試験サイト

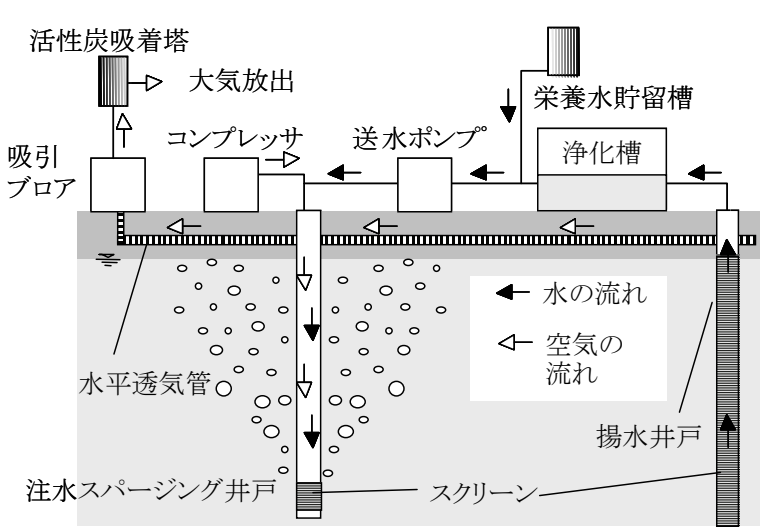

図-1 注水バイオスパージング工法の模式図

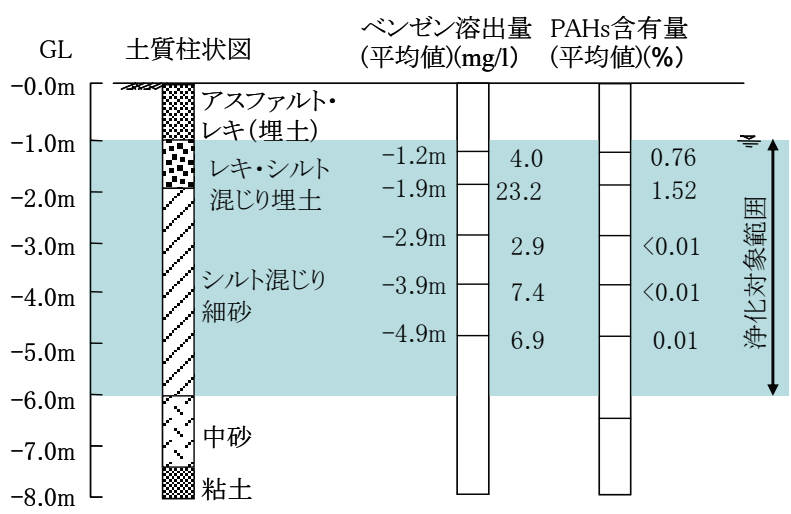

図-2 実証試験サイトの土質性状および污染状況

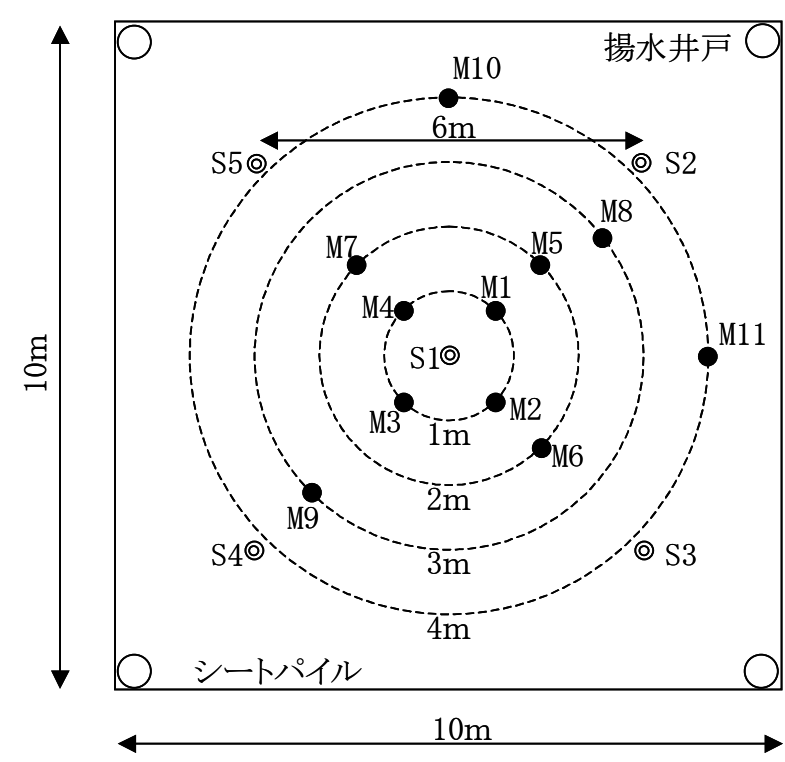

（）：スパージング井戸，○：観測井戸，○：揚水井戸

図-3 実証試験サイトの井戸平面配置図 
の地表面には，ガスを回収するための水平透気管を 平面的に $2 \mathrm{~m}$ 間隔で設置した後にアスファルトで被 覆し，スパージング工により地表面に気体として移 動するベンゼン污染ガスを全量回収可能な構造とし た. 試験サイトの任意の6地点から採取したボーリ ングコアサンプルについて, G.L.-1.2m, -1.9m, $-2.9 \mathrm{~m},-3.9 \mathrm{~m},-4.9 \mathrm{~m}$ 地点におけるベンゼン溶出量お よび主要な油分であるPAHs濃度（米国環境保護局 指定の16物質）を測定した結果，環境基準值を大き く超過するベンゼンが確認された（図-2）。また， G.L.-1.2m, G.L.-1.9m地点では, 高濃度のPAHsも観 測された（図-2）。

\section{3. スパージング影響範囲試験}

\section{(1) スパージング影響範囲試験の目的}

バイオスパージング工法では，スパージング井戸 から供給される空気の到達範囲（スパージング影響 範囲）に応じて，污染域に設置するスパージング井 戸本数を決定する必要がある。スパージング井戸の 影響範囲は，地盤の性状とスパージング井戸からの 空気供給量に影響を受ける。本章では，実証試験サ イトにスパージング井戸と複数の観測井戸を設置し てスパージング影響範囲試験を実施し，本サイトの スパージング井戸からの空気供給量に対する影響範 囲について検討した。

\section{(2) スパージング影響範囲試験の実施方法}

スパージング影響範囲は，スパージング井戸から 適当な間隔で観測井戸を設置し，スパージング風量 の増加に応じて管内圧力の上昇が生じる観測井戸ま での距離と定義した。図-3に実証試験サイトの井戸 平面配置を示す. 全長 $7 \mathrm{~m}$ （SGP管， $\phi 50 \mathrm{~mm}$, スク リーン位置G.L.-6.0〜-6.5m）のスパージング井戸 （S1）は，試験エリアの中心部に設置した。また， 全長 $5 \mathrm{~m}$ （VP管， $\phi 75 \mathrm{~mm}$ ，スクリーン位置G.L.-2.0 〜-5.0m）の観測井戸は, S1井から1〜 4mの距離に計 11本（M1〜M11）設置した. スパージング井戸の 管頭部配管には密閉形圧力計と風量計を接続し, 井 戸内圧力とスパージング風量を測定した。また，観 測井戸内部の圧力変化を把握するため, 観測井戸の 管頭部は密閉状態で井戸内の圧力変化を測定するた めの差圧計を装着できるサンプリング孔を設けた。

$\mathrm{S} 1$ 井からの空気供給量を $8.33 \times 10^{-4}, 1.67 \times 10^{-3}$, $2.50 \times 10^{-3}, 3.33 \times 10^{-3} \mathrm{~m}^{3} / \mathrm{s} \quad(50,100,150$ ， $200 \mathrm{~L} / \mathrm{min}$ ) に設定し, 約 20 分間連続的に空気を供 給して各観測井戸の内圧が定常状態に達しているこ

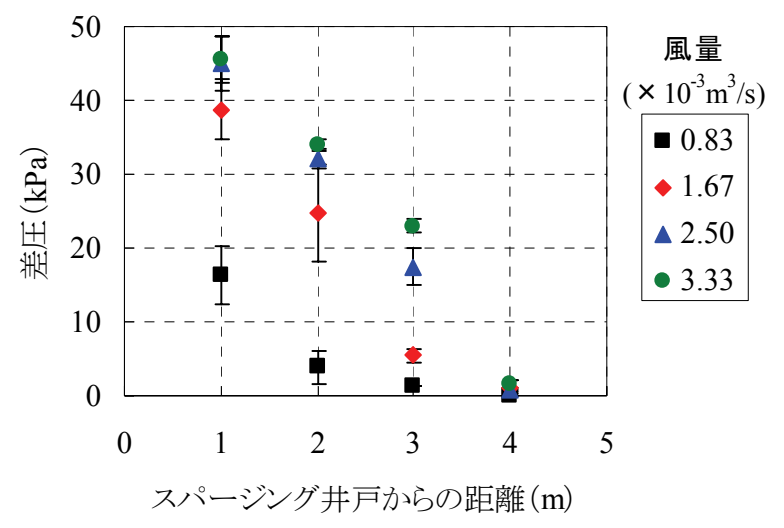

図-4 圧力上昇とスパージング井戸からの距離の関係

とを確認した後，スパージング井戸からの空気供給 量と観測井戸内の圧力変化を測定した.

\section{(3) スパージング影響範囲試験の結果}

$\mathrm{S} 1$ 井からの初期の空気供給量を $8.33 \times 10^{-4}, 1.67$ $\times 10^{-3}, 2.50 \times 10^{-3}, 3.33 \times 10^{-3} \mathrm{~m}^{3} / \mathrm{s} \quad(50,100,150$, $200 \mathrm{~L} / \mathrm{min}$ ）に設定して 20 分間連続的に空気を供給 した後のスパージング風量は，それぞれ $9.33 \times 10^{-4}$, $1.62 \times 10^{-3}, \quad 2.50 \times 10^{-3}, \quad 3.43 \times 10^{-3} \mathrm{~m}^{3} / \mathrm{s} \quad(56,97$, $150 ， 206 \mathrm{~L} / \mathrm{min}$ ) となり，初期設定流量と比較して 大きな変動は確認されなかった。また，各流量設定 に対するスパージング井戸内圧力は，それぞれ 0.06 , $0.075,0.09,0.10 \mathrm{MPa}$ であり, 空気供給量にほぼ比 例して増加した。 スパージング井戸から 1，2，3， $4 \mathrm{~m}$ 地点の観測井戸で計測した圧力を平均化し，ス パージング井戸からの距離と観測井戸内の圧力上昇 の関係を求めた結果を図-4 に示す.この結果, S1 井から $3 \mathrm{~m}$ 以内の観測井戸では空気供給量の上昇と ともに観測井戸内の圧力上昇が確認されたが，S1 井から $4 \mathrm{~m}$ に位置する観測井戸では空気供給量を増 加させても観測井戸内での有意な圧力上昇は確認さ れなかった。したがって，スパージング井戸の影響 半径は 3〜 4mの範囲であると推定された.

\section{4. 浄化確認試験におけるベンゼンの挙動}

\section{(1) 浄化確認試験の目的}

前章のスパージング影響範囲試験の結果から，ス パージング井戸の適切な配置間隔に関する知見が得 られた。本章では，スパージング工および注水バイ オスパージング工を実施し, 両浄化技術の実施時に おけるベンゼンの濃度変化とその浄化要因について， 地上に気化回収されたガス中のベンゼン濃度, 地下 
水中のベンゼン濃度, 土㙥のベンゼン溶出量を測定 することにより評価した.

\section{(2) 浄化確認試験の実施方法}

スパージング影響範囲試験の結果から，互いのス パージング井戸の空気到達範囲が近接井戸と重なる ように，スパージング井戸間隔を影響半径 $3 \mathrm{~m}$ の $\sqrt{2}$ 倍の $4.2 \mathrm{~m}$ として, 4 本のスパージング井戸 (S2〜 S5）を追加して設置した（図-3）。また，全長 $2 \mathrm{~m}$, 直径 $30 \mathrm{~cm}$ の揚水井戸をサイトの 4 隅に設置した

(図-3).

井戸から揚水した地下水は, 油水分離装置, 凝集 沈殿装置, 曝気処理装置, 活性炭処理装置により地 下水中の污染物質を除去した。ささらに, 窒素源とし て硝酸アンモニウム, リン源としてリン酸二水素カ リウムとリン酸水素二カリウムを $1: 1$ のリン含有比 で混合した試薬を処理水に溶解することにより，栄 養水を作成した。また，スパージング井戸から地盤 に供給した空気は，地表下 $50 \mathrm{~cm}$ の位置に設置した 水平透気管から吸引ブロアを用いて全量回収し, 回 収ガス中に含まれる揮発性有機化合物は活性炭吸着 塔により除去した。

本試験では浄化初期（浄化開始から48 日目ま で）と浄化終了時（155 日目から 178 日目まで）は， 空気のみを地盤に供給するスパージング工を実施し, 55 日目から 154 日目までは注水バイオスパージング 工法による空気供給と栄養水の注入を断続的に実施 した.

各スパージング井戸からの空気供給量は, 図-4 の 試験結果から， $2.50 \times 10^{-3} \mathrm{~m}^{3} / \mathrm{s}(150 \mathrm{~L} / \mathrm{min})$ が適正で あると判断した。 また，注水バイオスパージング工 実施時の注水量は，揚水した地下水を処理して返送 可能な $1.67 \times 10^{-5} \mathrm{~m}^{3} / \mathrm{s}(1 \mathrm{~L} / \mathrm{min})$ に設定し， 5 本の注 水スパージング井戸から均等に注水を行った。浄化 試験実施時の栄養塩の投入積算量および注水積算量 を図-5に示寸。浄化期間中の総注水量は約 $100 \mathrm{~m}^{3}$ で あり, 注水に用いる処理水は注水量と同量の地下水 を随時，揚水井戸から揚水して確保した。

地上部から回収した吸引ガス中のベンゼン濃度は, 活性炭吸着塔の流入配管に設置したガス採取孔から 採取して検知管により測定した。浄化期間中の地下 水中のベンゼン濃度は，図-3に示寸11箇所の観測井 戸から定期的に地下水を採取して測定した。土䁃中 のベンゼン濃度の減少については，S1井から $1 \mathrm{~m}$ 離 れた観測井戸4地点の近傍で浄化開始前, 注水バイ オスパージング工法開始前, 浄化終了時にボーリン グ調査を実施し, 浄化対象とする帯水層のベンゼン
溶出量およびPAHs含有量を測定した。ベンゼンの 地下水濃度および土壌溶出量については, ヘッドス ペースGC-MS法により測定した ${ }^{20)}$ 。また，PAHs含 有量については，土壌中の油分を二硫化炭素で抽出 後, GC-MS法により測定した ${ }^{21)}$.

\section{(3) 浄化確認試験の結果}

土壤中のベンゼン溶出量および PAHs 含有量の推 移を表-1に，浄化開始前に採取したベンゼン污染土 壌の溶出量と含有量の関係を図-6に, 試験期間中の サイト内のベンゼンガス回収量を図-7に，注水バイ オスパージング工実施期間中の揚水処理により回収 したベンゼン積算量を図-8 に示す。 また，M1〜M4 観測井戸（土壌調查と同一地点）から採取した地下 水中のベンゼン濃度平均值を図-9に, 浄化期間中の 地下水の平均温度を図-10に示す。

浄化初期に実施したスパージング工（浄化開始か ら48 日目まで）では，ベンゼンの地上部への物理 的回収に伴い, 地下水中のベンゼン濃度が低下する という関係が確認された。スパージング工終了時の 土壤調査の結果, PAHs が検出されなかった G.L.-2 〜-6m の地点では, 土壌のベンゼン溶出量が 93\%減 少した。一方, PAHs が高濃度で残存する G.L.-1〜 $-2 \mathrm{~m}$ 地点では, ベンゼン溶出量の減少率は約 $43 \%$ と 低く, ベンゼンが高濃度で帯水層中の土袞に残存し た. ベンゼンの気化効果が小さかった原因として, 污染源に存在する PAHs を主成分とする油分にベン ゼンが溶解しているため，気化効果が妨げられたも のと推察した.

地下水中のベンゼン濃度は，浄化開始から40日 間で急激に減少したが，その後の約 90 日間は有意 な減少が確認されなくなった。浄化開始から 129 日 後（注水バイオスパージング工を導入して 74 日 後）にベンゼン濃度は再び減少し始め, 浄化終了時 には環境基準值 $(0.01 \mathrm{mg} / \mathrm{L})$ 近くまで減少した。こ れに伴い, 試験終了時の G.L.-2〜-6m 地点の污染拡 散域における土壌のベンゼン溶出量は環境基準值ま で低減することを確認した。また， G.L.-1〜 - 2m 地 点の污染源においても, ベンゼン溶出量はスパージ ング工終了時と比較して約 $70 \%$ 低減した。

本試験において，スパージング工および注水バイ オスパージング工実施期間中の，浄化対象污染地盤 でのベンゼン収支を表-2 に示す。スパージング工実 施期間中のベンゼンの気化効果による回収量は，地 盤内におけるベンゼン減少量の $96 \%$ を占め, 浄化 初期においては大部分のベンゼンが物理的に除去さ れることが示された. 


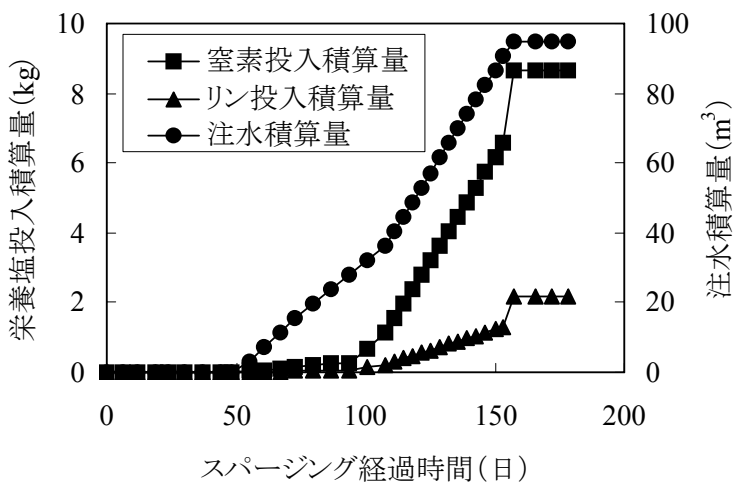

図-5 窒素・リンの投入積算量および注水積算量

表-1 土壌のベンゼン溶出量および PAHs 含有量の推移

\begin{tabular}{|c|c|c|c|}
\hline \multirow[b]{2}{*}{ 土鎄調査日 } & \multicolumn{2}{|c|}{ 土壤ベンゼン溶出量平均値*(mg/L) } & \multirow{2}{*}{$\begin{array}{c}\text { 土壤PAHs含有量 } \\
\text { 平均値 } *(\%) \\
(\text { G.L.-1 } \sim-2 \mathrm{~m})^{* *}\end{array}$} \\
\hline & $\begin{array}{c}\text { 污染拡散域 } \\
(\text { G.L.-1 - } 2 \text { - } 2 \text { )** }\end{array}$ & $\begin{array}{c}\text { 污染拡散域 } \\
(\text { G.L.-2 } 2 \sim-6 \mathrm{~m})^{* * * *}\end{array}$ & \\
\hline 0日(試験開始前) & 18.84 & 5.57 & 1.41 \\
\hline 48日(スパージング工終了時) & 10.66 & 0.38 & 1.61 \\
\hline 178日(淕験終了時) & 3.17 & 0.01 & 1.01 \\
\hline
\end{tabular}

*M1〜 M4 地点(初期)およびその近傍の土壤コアサンプルの平均值

${ }^{*}$ G.L.-1.2mおよびG.L.-1.9mの2地点から採取した誡料の平均值

***G.L.-2.9m,G.L.-3.9mおよびG.L.-4.9mの3地点から採取した試料の平均值

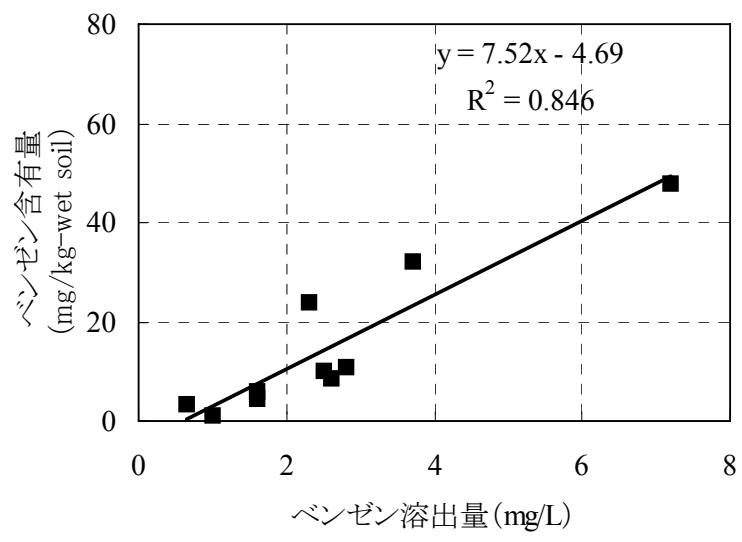

図-6 ベンゼン溶出量と含有量の相関関係

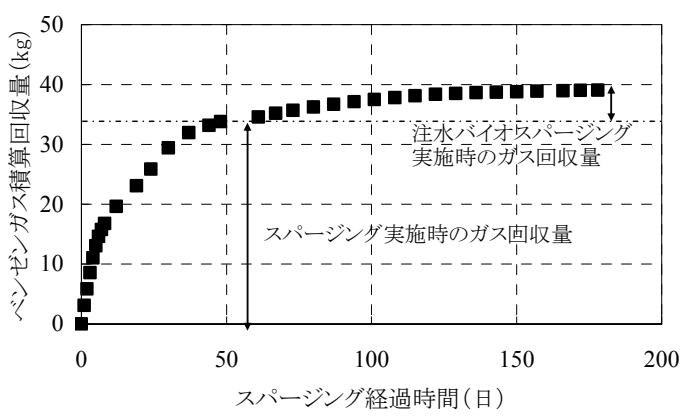

図-7 気化によるベンゼン回収量の推移

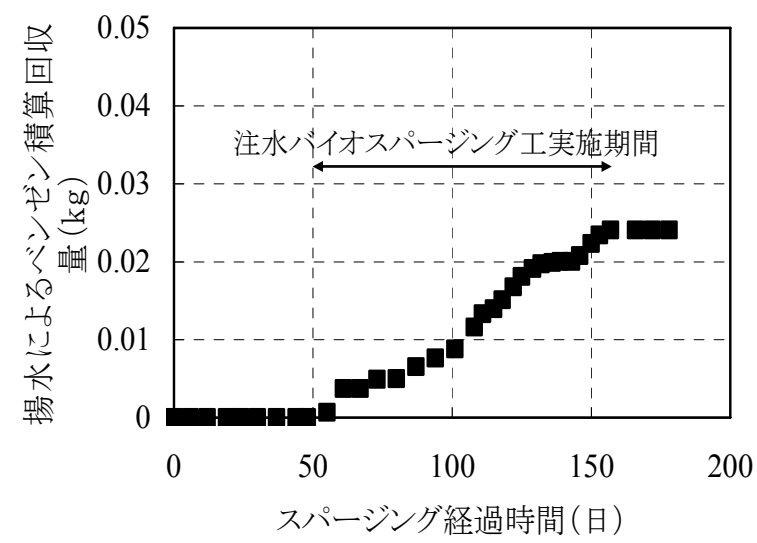

図-8 揚水によるベンゼン回収量の推移

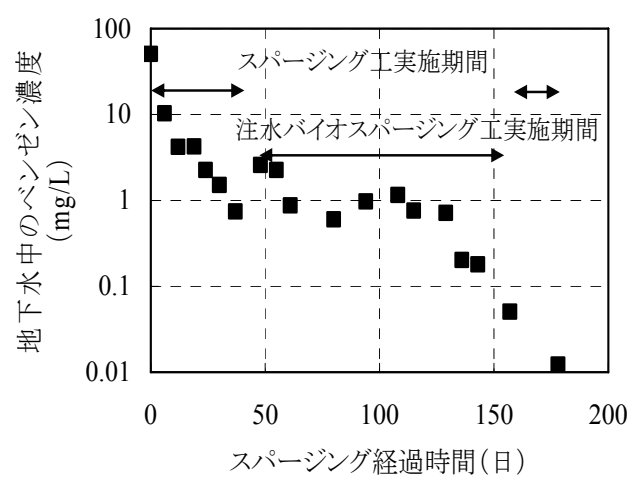

図-9 地下水中のベンゼン濃度の推移 (S1井から $1 \mathrm{~m}$ 地点の観測井戸における平均值)

一方，注水バイオスパージング工の導入後から浄 化終了時までの気化効果によるベンゼン回収量は 43\%と大きく低下した。揚水によるベンゼンの回収 量は $0.2 \%$ と非常に小さかったことから，本工法導 入後のベンゼン濃度の減少は, 地盤からの物理的回 収効果以外の要因により進行したものと推察された。 この要因として，G.L.-1〜-2m地点の非揮発性の油 分であるPAHs含有量が減少したこと, 試験期間を 通じて帯水層中の土垬温度が $20^{\circ} \mathrm{C}$ 前後に保たれてい たことから, 注水バイオスパージング工により帯水 層中の好気性細菌の分解活性が向上し, ベンゼンの 分解が促進されたものと考えられた。

\section{5. トレーサー試験による栄養塩の拡散と消費 状況の確認}

(1) トレーサー試験の目的

注水バイオスパージング工の導入により，地盤中 の微生物分解効果が高まり, 浄化が促進される可能 
性があることが, 前章の浄化確認試験の結果から示 された。一方，ベンゼン分解菌を含む好気性細菌を 長期的に活性化させるためには，窒素およびリンな どの栄養塩の供給が必要である ${ }^{22)}$. 微生物による分 解効果を証明するには，スパージング井戸から供給 された栄養塩がサイト全体に供給され, サイト内で 消費されていることを示す必要がある. 本章では, 栄養水の地盤内の拡散状況をトレーサー物質により 確認し，投入した栄養塩の消費状況を観測すること により, 地盤内での微生物分解効果を検証した.

\section{(2) トレーサー試験の実施方法}

スパージング井戸を利用して帯水層に供給した栄 養水の拡散状沉を把握するため, 試験開始61日後

（注水バイオスパージング工開始から6日後）にS1 井から臭化ナトリウム $10 \mathrm{~kg}$ （臭化物イオン換算で $7.76 \mathrm{~kg}$ ）を投入し，投入後の各観測井戸における臭 化物イオン濃度を定期的に測定した。また， S1井か ら $1 \mathrm{~m}$ 地点にある4力所の観測井戸における地下水中

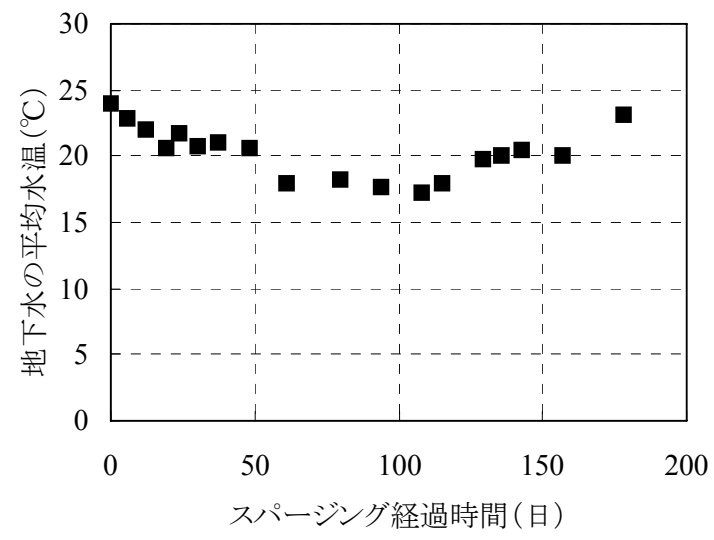

図-10 地下水中の平均水温の推移

表-2 試験期間中の気化および揚水によるベンゼン回収率

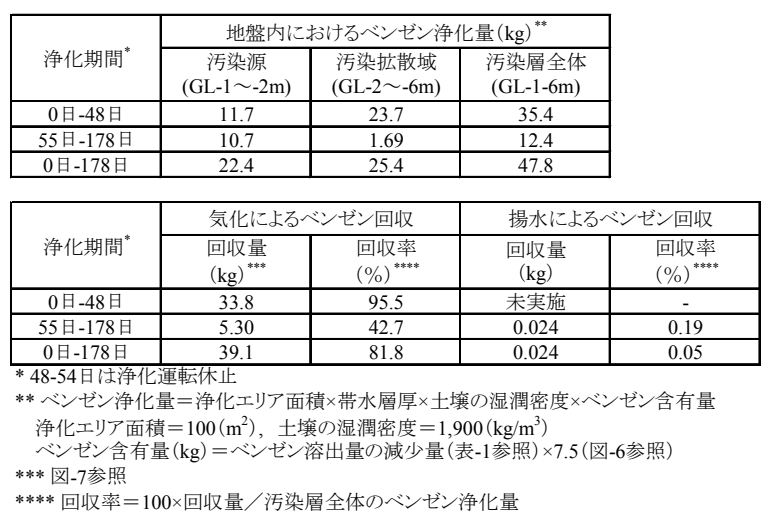

の溶存性全窒素（DTN）濃度および溶存性全リン （DTP）濃度を測定した。 臭化物イオン，DTN およ び DTP 測定用の地下水は, 採水直後に滅菌済みの $0.45 \mu \mathrm{m}$ ディスクフィルターで濾過処理を行った. 臭化物イオンについては HPLC ${ }^{20)}$, DTN および DTP については試料 $50 \mathrm{ml}$ に対して水酸化ナトリウ ムーペルオキソ二硫酸カリウム溶液 ${ }^{23)} 10 \mathrm{ml}$ 添加 して高圧蒸気滅菌器を用いて $121^{\circ} \mathrm{C} て ゙ 30$ 分間分解処 理し, 分解処理溶液中の硝酸態窒素濃度 ${ }^{20)}$ および オルトリン酸態リン濃度 ${ }^{24)}$ を測定して求めた.

\section{(3) トレーサー試験結果}

臭化物イオン濃度の推移を図-11に示す。スパー ジング井戸から $1 \mathrm{~m}$ 地点においては，トレーサーの 投入開始6日後（浄化開始から67日後）において高 濃度のトレーサーが検出され，スパージング井戸の 近傍では短時間で栄養塩が供給されていることが確 認された。また，トレーサーの投入から117日目に は各観測井戸におけるトレーサー濃度はほぼ同様の 值となり, 注入された臭化物イオンがほぼ均一に拡 散していることを確認した.

$\mathrm{S} 1$ 井から $1 \mathrm{~m}$ 地点にある4力所の観測井戸における 地下水中のDTNおよびDTP（共に平均值）の推移を 図-12に示す。注水終了時までに带水層に供給され た栄養塩は, 地下水中の窒素濃度およびリン濃度を それぞれ平均で $23 \mathrm{mg} / \mathrm{L}, 5.7 \mathrm{mg} / \mathrm{L}$ 増加させる投入量 であるのに対し, 注水開始後の地下水中の窒素濃度 の増加量は $5 \mathrm{mg} / \mathrm{L}$ 以下で推移し, リン濃度の増加は 確認されなかった。投入した栄養塩の大部分が消費 されたことより, 注水バイオスパージング工実施期 間中の地盤内におけるベンゼン濃度の減少は, 微生 物分解の結果である可能性は高いと判断された. こ れらの結果から, 注水バイオスパージング工は, 気 化効果と微生物分解効果の相乗効果により, 地盤中 のベンゼンを効率的に浄化できる工法であることを 確認した.

\section{6. 注水スパージング井戸の注水効率の検討}

\section{(1) 注水試験の目的}

注水スパージング井戸から空気と共に栄養水を供 給する本工法では，栄養水の注入効率が既存の注入 技術と比較して高まることが予測されるが，実測に より確認した事例はない. 本章では, スパージング 井戸を用いて, 自然浸透条件（リチャージ工法）と 


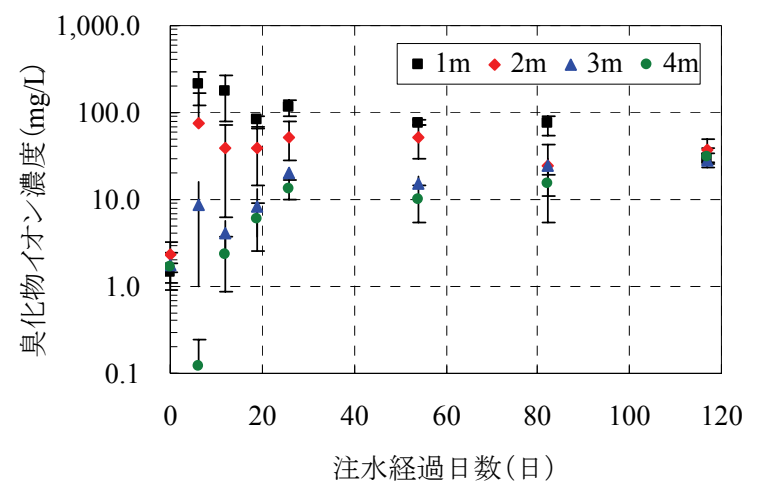

図-11 臭化物イオン濃度の推移

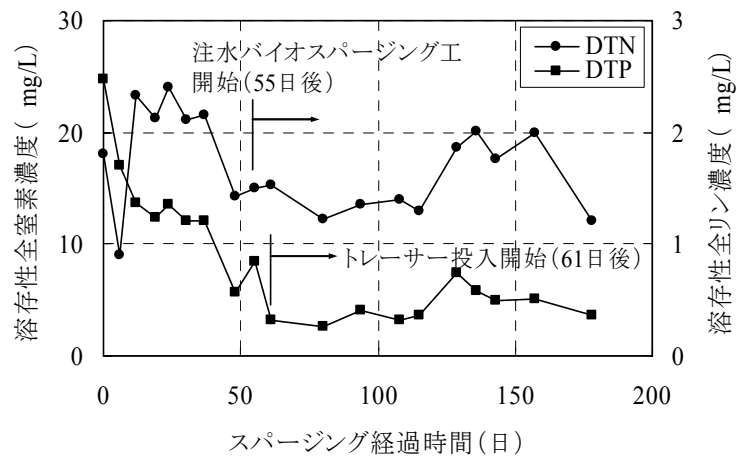

図-12 溶存性全窒素および溶存性全リンの推移

注水バイオスパージング工法との栄養水注水能力を 同一の井戸を用いる原位置試験により比較検討した

\section{(2) 注水試験方法}

浄化確認試験の実施後にS1井の管頭部分の配管を 外し，単孔を利用した透水試験方法 ${ }^{25)}$ に基づく原 位置透水試験を行った。揚水井戸および観測井戸か ら揚水処理を行い, 試験開始時の地下水位を G.L.$3.8 \mathrm{~m}$ に低下させた。本試験では，井戸の水位を水道 水により一時的に管頭付近まで上昇させ，平衡状態 に戻るまでの水位変化を 10 秒毎に5分間測定し，本 井戸をリチャージ井戸として使用した場合の自然浸 透速度を算出した。

注水バイオスパージング工法による注水試験では, 初めに注水を実施せず，風量調整バルブを開放して 風量を徐々に上昇させながら $2.50 \times 10^{-3} \mathrm{~m}^{3} / \mathrm{s}$ (150L/min) まで増加させ，その間の空気供給量と 井戸内圧力の計測を行った。風量が $2.50 \times 10^{-3} \mathrm{~m}^{3} / \mathrm{s}$

（150L/min）に到達した時点で，風量調整バルブを 固定したまま注水量調整バルブを開放して注水を開 始して一定の注水量で約20分間連続して注水を行い, 定常状態での安定した水供給が行われていることを 確認した。ささらに，注水量を徐々に増やしながら同
様の注水試験を実施し，注水量に対する風量とスパ ージング井戸内圧力の計測を行った.

\section{(3) 注水試験結果}

透水試験による透水係数は $1.1 \times 10^{-5} \mathrm{~m} / \mathrm{s}$ と算出され， S1井の地表面で水頭圧を維持した場合の帯水層に対 する自然浸透速度は $8.33 \times 10^{-6} \mathrm{~m}^{3} / \mathrm{s} \quad(0.5 \mathrm{~L} / \mathrm{min})$ と算 出された。図-13に注水によるスパージング井戸内 圧力と風量の関係を示す。風量が $2.50 \times 10^{-3} \mathrm{~m}^{3} / \mathrm{s}$ （150L/min）で安定した後に注水を実施した結果， 自然浸透速度の 8 倍に相当する $6.67 \times 10^{-5} \mathrm{~m}^{3} / \mathrm{s}$

(4L/min) の注水量においても，スパージング井戸 から安定した水供給が行われていることを確認した 注水量を増加させていく過程で，スパージング井戸 内圧力の上昇および空気供給量の低下に正の相関が 認められ，井戸スクリーンにおける空気の通過抵抗 が徐々に大きくなることが示された.

この結果から, 地盤の割裂等による特定の流路が 形成されるなどの問題は生じずに, 注水スパージン グ井戸を用いて栄養水を自然浸透条件よりも最大で 8倍高く供給できることを確認した。

\section{7. 設計手法の検討}

\section{(1) 設計手法の目的}

注水バイオスパージング工法の適用までの設計手 法を図-14 に示す。本工法を様々なサイトで適用し ていくためには，浄化対象とする污染域で実施する スパージング影響範囲試験の結果から, 注水スパー ジング井戸の最適な空気供給量や配置条件を決定す る手法が必要である。 また, 注水井戸からの風量や 注水量などの仕様に応じて, 浄化期間を予測する手 法を確立することも重要である.

本章では，本実証試験から得られた結果を用いて これらの設計手法の検討を行い，それぞれのフェー ズで正しく評価が行えることを確認する。

\section{（2）理論式に基づくスパージング影響範囲の検討}

スパージング工法に対して影響範囲を評価する方 法としては, 原位置試験結果を用いて, 観測井戸内 の圧力上昇とスパージング井戸からの距離の関係か ら，圧力上昇がゼロ（大気圧）となる距離を外挿し て求める方法が挙げられる。しかしながら，スパー ジング影響範囲を表すスパージング井戸からの距離

(影響半径）に関する幾つかの報告 ${ }^{26), 27,28), 29,30) か ゙ さ ~}$ れている一方，設計手法を導き出せる評価方法は存 在していない。一方，地下より揮発性有機化合物を 
回収する浄化技術の一つである土壌ガス吸引法（以 下，SVE）については，浄化井戸からのガス吸引に 伴う影響範囲に関する理論式が多く報告 7),31),32) され ており, 浄化井戸の配置設計に積極的に取り入れら れている，そこで，本節ではS SVE サイトで提案さ れている理論式を本浄化工法の設計手法として導入 し，適用性について評価する。

式(1a)は，均質多孔質中の無限境界地盤における 気体の定常軸対象一様流れの理論式 33 である.SVE サイトで提案されている理論式の中では, 最も簡易 的な式と言える. 式(1a)を $r=r_{1}$ で $P=P_{1}, r=r_{2}$ で $P=P_{2}$ な る境界条件を用いて $P$ にいて整理すると, 式(1b) に示寸圧力の式が導出される.

$$
\begin{gathered}
\frac{d^{2} P^{2}}{d r^{2}}+\frac{1}{r} \frac{d P^{2}}{d r}=0 \\
P^{2}=\frac{P_{2}^{2}-P_{1}^{2}}{\ln \left(r_{2} / r_{1}\right)} \ln (r)+\frac{P_{1}^{2} \ln \left(r_{2}\right)-P_{2}^{2} \ln \left(r_{1}\right)}{\ln \left(r_{2} / r_{1}\right)}
\end{gathered}
$$

ここで， $P_{1}, P_{2}$ おび $r_{1}, r_{2}$ は，それぞれ観測圧 (Pa)およびスパージング井戸からの距離 $(\mathrm{m})$ である. また，スパージング井戸からの空気供給量は式(2a) のように導出され， $r_{2}$ につて整理すると式(2b)が 導出される， $P_{2}$ を大気圧とすると, 式(2b)から求ま る $r_{2}$ はスパージング井戸から大気圧となる地点まで の距離となり，影響半径を算定できる.

ここで， $Q_{v}$ は空気供給量 $\left(\mathrm{m}^{3} / \mathrm{s}\right), k$ は透過度 $(1.15 \times$ $\left.10^{-13} \mathrm{~m}^{2}\right), P^{*}$ は注入圧 $(\mathrm{Pa}), \mu$ は空気の粘性係数 $(1.82$ $\left.\times 10^{-5} \mathrm{~Pa} \cdot \mathrm{s}, 20^{\circ} \mathrm{C}, 1.01 \times 10^{3} \mathrm{hPa}\right), b$ は带水層厚 (5.0m)である.

$$
\begin{gathered}
Q_{v}=-\frac{\pi b k\left(P_{2}^{2}-P_{1}^{2}\right)}{P^{*} \mu \ln \left(r_{2} / r_{1}\right)} \\
r_{2}=r_{1} \exp \left(-\frac{\pi b k\left(P_{2}^{2}-P_{1}^{2}\right)}{Q_{v} P^{*} \mu}\right)
\end{gathered}
$$

表-3 に空気供給量に対する影響半径の算定結果を 示し, 図-15 に圧力上昇とスパージング井戸からの 距離の関係を示寸ここれらの算定にあたっては, 各 観測圧に対する再現性を考慮して， $r_{1}=3 \mathrm{~m}$ における 観測圧 $\left(P_{1}\right)$ を用いた。ここで, 表-3 に示した算定結 果から， $3.33 \times 10^{-3} \mathrm{~m}^{3} / \mathrm{s} （ 200 \mathrm{~L} / \mathrm{min} ）$ における影響半 径は, $2.50 \times 10^{-3} \mathrm{~m}^{3} / \mathrm{s}(150 \mathrm{~L} / \mathrm{min})$ よりも小さい結果 となった.この物理的な要因としては, 地盤の不均

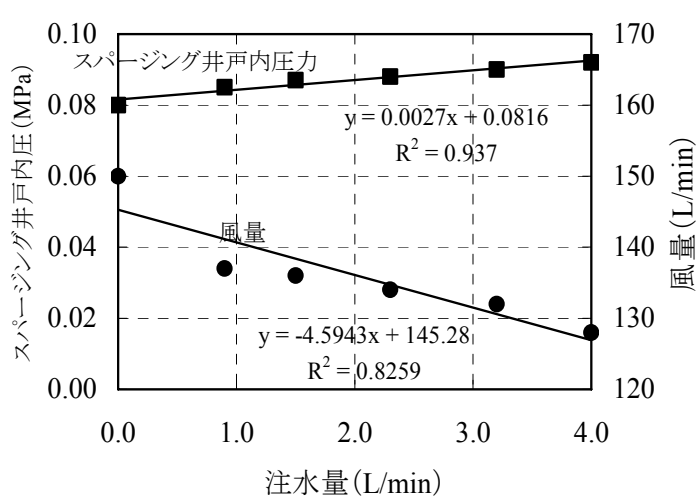

図-13 注水によるスパージング井戸内圧力と風量の変化

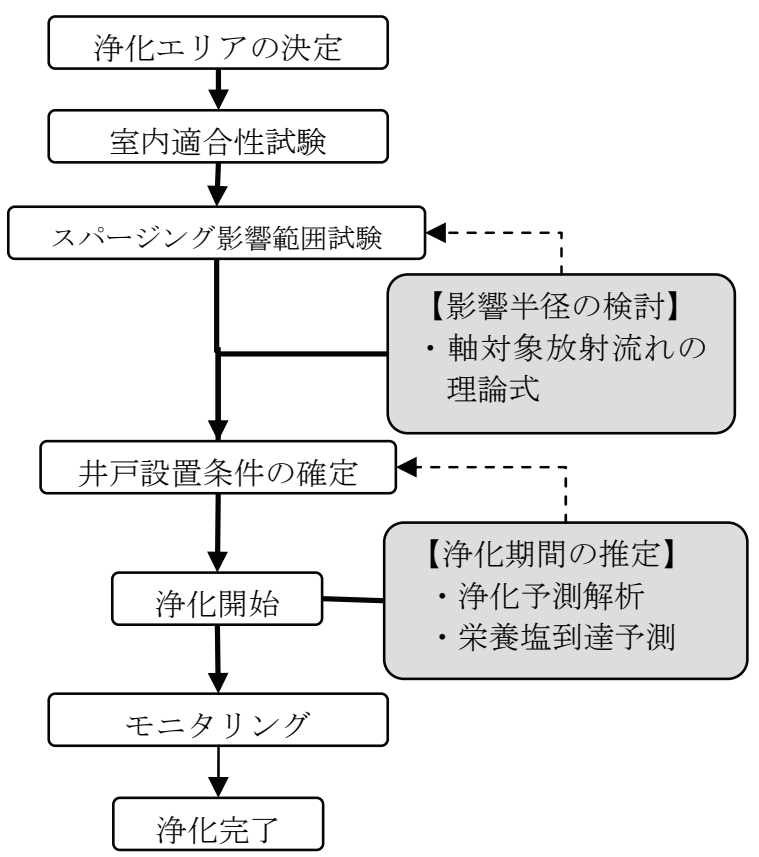

図-14 設計手法の全体フロー

一性や浮力による圧力損失の影響が，空気供給量に 対する圧力上昇の妨げになったことが考えられる.

このように, スパージング工法では, 空気供給量 の大きさに比例して影響半径が拡大寸る傾向が成立 しなくなる領域があると推察され, 効率的な浄化を 行うための適正な空気供給量が存在する。これは, 図-15に示したスパージング井戸から4m地点におけ る圧力上昇の観測結果からも明白である.

したがって、スパージング影響範囲試験の結果か ら理論式(2b)を用いて影響半径を推定し, 適正な空 気供給量を決定する手法は有効であると判断された。

EPAのバイオスパージング工法に対する設計手法

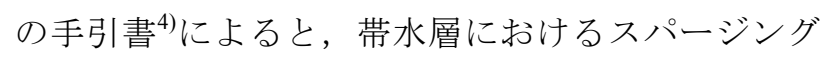
影響半径は, SVEの空気吸引による影響半径に対し 
て40〜80\%程度となることが述べられている。これ は，SVEとスパージング工法を比較した場合，同一 風量ではスパージング工法の影響半径の方が小さく なることを示唆している.

ここで，最適空気供給量 $2.50 \times 10^{-3} \mathrm{~m}^{3} / \mathrm{s}$ (150L/min) におけるスパージング影響範囲試験の 実測から得られた影響半径 $(3 \sim 4 \mathrm{~m})$ は，理論式 (2b)から求めた影響半径（9.15m） に対して $30 〜 40 \%$ となり，EPAが指摘する影響半径の最下限の低減傾 向に対応した結果となった。この低減率はスパージ ングを行う深度, 地下水位, 帯水層の透水性などに より変化するものと推測されるため, 影響範囲の決 定には第3章の原位置試験を実施することが基本と なる. 今後, 様々なサイトの地盤条件に対する低減 率を蓄積することにより，影響半径の算定結果に対 して適切な低減率を与えることが可能になると考え ている。

\section{(3) 浄化確認試験に基づく浄化予測手法の検討}

第4章の結果を踏まえ, 事前に浄化期間の予測を 行うため, 浄化予測プログラム ${ }^{34)}$ (以降, 予測解 析）を用いたシミュレーションを実施し，本浄化工 法への適用性を評価する。

\section{a) 予測解析手法}

本予測解析手法は，SVEにおける浄化予測を簡便 に行うことを目的として開発されたプログラムであ る.SVEにおいてもスパージングにおいても，気相 および原液相を理想気体, 理想混合相として, ガス 排出量によって変化する各相（気相-原液-間隙水-固 相）の物質量のマスバランスを熱力学平衡により仮 定する限りにおいては，同等に算定することが可能 である（式(3)，式(4)）。ここで，式(4)に対しては 栄養塩の投与による微生物分解の効果を微生物分解 速度定数 $\lambda_{i}$ として新たに追加している.

$$
\begin{gathered}
M_{i}=x_{i}\left\{\frac{P_{i}^{V} \theta V}{R T}+M^{H C}+\frac{M^{H_{2} O}}{\alpha_{i}}+\frac{h_{i} M_{s}}{\alpha_{i} M_{w}}\right\} \\
\frac{d M_{i}}{d t}=-Q_{a} C_{a i}-\lambda_{i} M_{i}-Q_{w} C_{w i}
\end{gathered}
$$

ここに，式(3)の $M_{i}$ は $i$ 種の物質モル数 $(\mathrm{mol}), x_{i}$ は 原液相における $i$ 種の物質のモル分率, $P_{i}^{V}$ は $i$ 種の物 質の蒸気圧 $\left(1.01 \times 10^{3} \mathrm{hPa}\right), \quad \alpha_{i}$ は水中における $i$ 種の 物質の活動度係数（1.0）， $h_{i}$ は $i$ 種の物質と土との吸 着平衡定数, $\theta$ は間隙率, $V$ は土塊体積 $\left(\mathrm{m}^{3}\right), R$ は気 体定数, $T$ は土の温度 $\left(20^{\circ} \mathrm{C}\right), M^{H C}$ は原液相の全モル
表-3 空気供給量に対する影響半径算定結果

\begin{tabular}{|c|c|c|c|c|}
\hline $\begin{array}{c}\text { 空気供給量 } \\
\times 10^{-3}\left(\mathrm{~m}^{3} / \mathrm{s}\right) \\
(\mathrm{L} / \mathrm{min})\end{array}$ & $\begin{array}{c}0.83 \\
50\end{array}$ & $\begin{array}{c}1.67 \\
100\end{array}$ & $\begin{array}{c}2.50 \\
150\end{array}$ & $\begin{array}{c}3.33 \\
200\end{array}$ \\
\hline 影響半径 $(\mathrm{m})$ & 3.7 & 5.15 & 9.15 & 8.75 \\
\hline
\end{tabular}

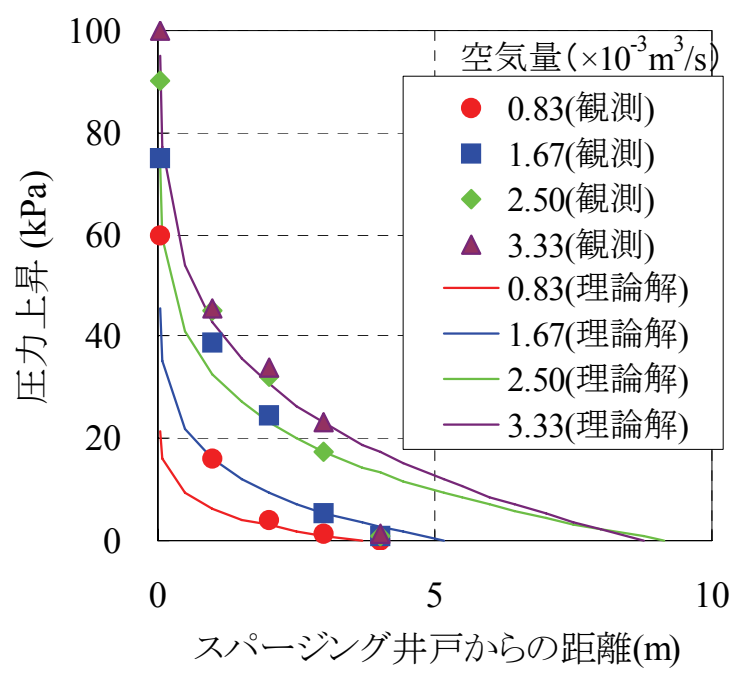

図-15 圧力上昇とスパージング井戸からの距離の関係

数 $(\mathrm{mol}), M^{\mathrm{H}_{2} \mathrm{O}}$ は間隙水の全モル数 $(\mathrm{mol}), M_{s}$ は污染 土塊の重量 $(\mathrm{kg}), M_{w}$ は水のモル重量 $\left(1.8 \times 10^{-2} \mathrm{~kg} / \mathrm{mol}\right)$ である。

また，式(4)の $Q_{a}$ は空気供給量 $\left(\mathrm{m}^{3} / \mathrm{s}\right), C_{a i}$ は気相中 の $i$ 種のモル濃度 $\left(\mathrm{mol} / \mathrm{m}^{3}\right), \lambda_{i}$ は微生物分解速度 $(1 / \mathrm{s})$, $Q_{w}$ は揚水量, $C_{w i}$ は揚水した地下水中のベンゼン濃 度である。表-2の結果から，本式の「 $\left.Q_{w} C_{w i}\right\rfloor$ に伴 うベンゼン減少は, 気化や微生物分解に伴う他の2 項の減少と比較して無視できるものと考えられるた め，解析では除外した。

\section{b) 栄養水の浸透速度の影響評価}

図-16に注水実施日における栄養塩投入量とベン ゼン濃度の関係を示す。栄養塩の投入はスパージン グ開始から55日後から実施したが，ベンゼン濃度の 明瞭な低下が見られなかったことから，101日後以 降に栄養塩の投入量を増加した. その後, 129 日後 以降に微生物によるベンゼン濃度の明瞭な減少が生 じた。このことから, 効果的な濃度の栄養塩が地中 一投入されてから, およそ 30 日程度で微生物分解効 果が発揮されたと推察される.

ここで，式(5)を用いて浄化対象範囲内の地下水が 栄養水に置換されるまでの時間を計算する. 
表-4 地下水置換時間算定結果

\begin{tabular}{|c|c|c|c|}
\hline $\begin{array}{c}\text { 間隙率 } \theta \\
(-)\end{array}$ & $\begin{array}{c}\text { 対象範囲 } r \\
(\mathrm{~m})\end{array}$ & $\begin{array}{c}\text { 帯水層厚 } b \\
(\mathrm{~m})\end{array}$ & $\begin{array}{c}\text { 置換時間 } t \\
(\mathrm{~s})\end{array}$ \\
\hline 0.3 & 1.0 & 5.0 & $\begin{array}{c}2.45 \times 10^{6} \\
\fallingdotseq 28(\text { 日 })\end{array}$ \\
\hline
\end{tabular}

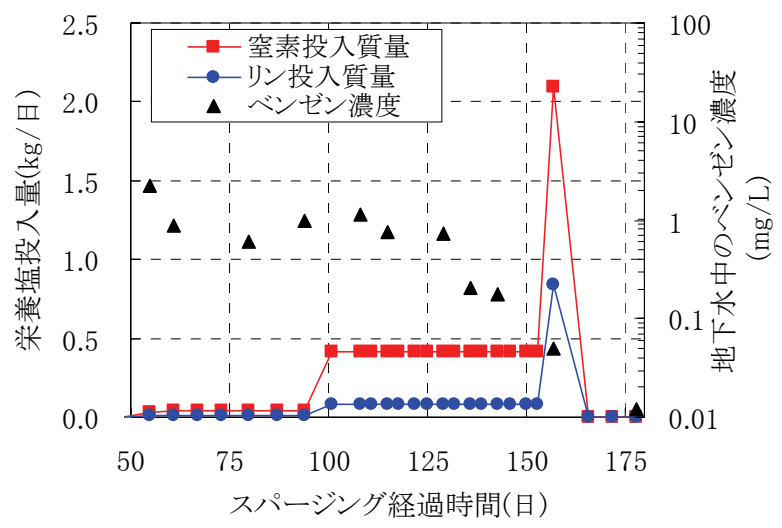

図-16 栄養塩投入量とベンゼン濃度の関係

表-5 予測解析に用いた条件一覧

\begin{tabular}{|c|c|c|c|c|}
\hline $\begin{array}{c}\text { 空気 } \\
\text { 注入量 } Q_{a} \\
\left(\mathrm{~m}^{3} / \mathrm{s}\right)\end{array}$ & $\begin{array}{l}\text { 土塊 } \\
\text { 体積 } V \\
\left(\mathrm{~m}^{3}\right)\end{array}$ & $\begin{array}{c}\text { 間隙率 } \\
\theta \\
(-)\end{array}$ & $\begin{array}{c}\text { 吸着平衡 } \\
\text { 定数 } h_{i} \\
(-)\end{array}$ & $\begin{array}{c}\text { 微生物 } \\
\text { 分解速度 } \\
\lambda_{i}(1 / \mathrm{s})\end{array}$ \\
\hline \multirow{2}{*}{$\begin{array}{c}2.5 \times 10^{-3} \\
(150 \mathrm{~L} / \mathrm{min})\end{array}$} & \multirow{2}{*}{15.7} & \multirow{2}{*}{0.3} & *10.6 & \multirow{2}{*}{${ }^{* * *} 7.5 \times 10^{-7}$} \\
\hline & & & ${ }^{* *} 73.3$ & \\
\hline
\end{tabular}

*地下水中のベンゼン濃度 $>1.0 \mathrm{mg} / \mathrm{L}$ 時に適用

**地下水中のベンゼン濃度 $<1.0 \mathrm{mg} / \mathrm{L}$ 時に適用

***微生物分解効果が促進されたと考えられる129日以降から適用

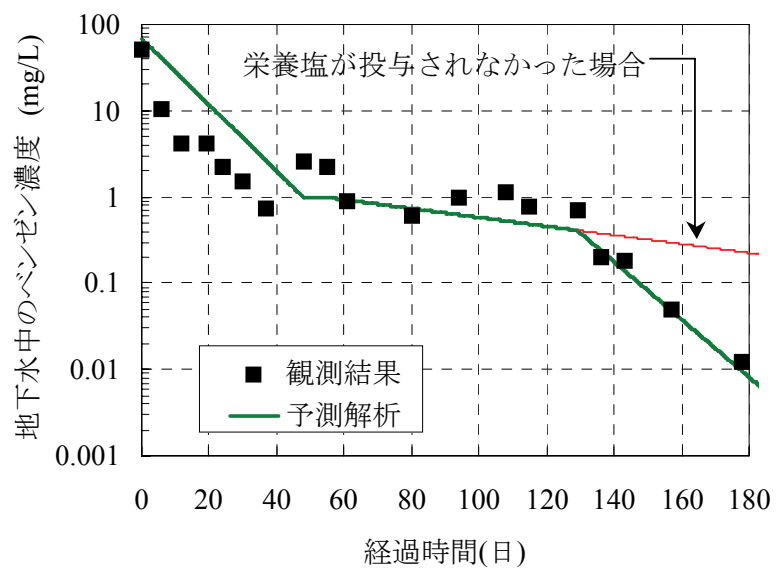

図-17 注水効果に伴うベンゼン濃度の低下予測

$$
t=\frac{\theta \pi r^{2} b}{Q}
$$

ここに， $\theta$ は間隙率(-), $r$ は対象範囲半径 $(\mathrm{m}), b$ は浄化対象の帯水層の厚さ $(\mathrm{m}), Q$ は栄養水の注入 量 $\left(\mathrm{m}^{3} / \mathrm{s}\right), t$ は時間 $(\mathrm{s})$ である.

式(5)による地下水の置換時間の算定結果を表-4に 示す。栄養水注入量 $Q$ は, 本実証試験のスパージン グ井戸一本当りの注入水量である $1.92 \times 10^{-6} \mathrm{~m}^{3} / \mathrm{s} （ \fallingdotseq$ $0.115 \mathrm{~L} / \mathrm{min}$ ）を用いる。算定の結果，栄養水が対象 範囲の間隙地下水を置換するために要する時間は28 日と求められた。この算定結果は, 効果的な濃度の 栄養塩投入を開始してから微生物の効果が生じるま での時間に対応している。

\section{c) 浄化確認試験結果への適用}

予測解析に用いる入力条件を表-5に示す。土塊体 積は，污染対象範囲を半径 $1 \mathrm{~m}$, 高さ $5 \mathrm{~m}$ の円柱形と して設定した。また，表中の吸着平衡定数は，固相 に吸着したベンゼンの脱着速度が低下する傾向を観 測結果と整合するように感度解析的に求めた。 そし て，微生物分解速度に関しても，129日以降の濃度 低下を表現する值を感度解析的に求めている．微生 物分解速度を導入する 129 日は, 効果的な濃度の栄 養塩が投入開始されたと考えられる101日後から， 式(5)を用いて算定した置換時間である28日を加えた 経過日数である.

図-17に，地下水中のベンゼン濃度の実測值と予 測解析の比較を示す。予測解析結果は, ベンゼン濃 度の減少挙動をほぼ再現でき, 栄養水が土壌間隙に 充填された後にベンゼンの微生物分解が生じる現象 を本工法の浄化予測モデルとして適用できることが 示された。今後, 本解析手法を様々な地盤条件（温 度，透水性）で実施する注水バイオスパージング工 法に適用し，吸着係数および微生物分解速度などの 解析值を収集することにより，地盤条件に応じた浄 化期間の予測精度が向上していくと考えている.

ここで，効果的な濃度の栄養塩が投入されなかっ た場合を想定し，129日後以降の予測解析を実施し た（図-17）。その結果，本実証試験では，微生物 分解により地下水中のベンゼン濃度は，浄化開始か ら200日以内に環境基準值以下に減少することが予 測できた。一方，栄養塩を投入しなかった場合，べ ンゼン濃度が環境基準值以下となる時間は，およそ 440 日程度と求められた。 したがって, 注水バイオ スパージング工法を適用したことによって，従来の スパージング工法と比較して，200日以上の早期浄 化が達成されたことが本解析により示された。 


\section{8. 結論}

本稿では，揚水循環併用バイオスパージング工法 の実証試験結果を精査し，従来工法と比較して，心゙ ンゼン污染带水層に対する浄化効果が向上すること を確認した。また，本工法を適用する浄化計画を行 う際に，スパージング風量や浄化期間などの設計仕 様を簡便な理論式により求める設計手法の妥当性に ついても検討を行った。

得られた知見を以下にまとめる.

（1）スパージング影響範囲試験を実施した結果，本 サイトの空気到達範囲は $3 \sim 4 \mathrm{~m}$ の範囲であった。 SVEにおいて用いられている簡便な理論式を本 試験結果に適用した結果， $2.50 \times 10^{-3} \mathrm{~m}^{3} / \mathrm{s}$ （150L/min）の場合に影響半径は最大值 （9.15m）を示し，最適空気供給量であること を確認した。実測值の影響半径は，理論式から 求めた算定結果の $30 \sim 40 \%$ となった.

（2）地下水中のベンゼン濃度が $1 \mathrm{mg} / \mathrm{L}$ 超過する浄 化初期には，ベンゼンは物理的な気化効果によ り効率良く除去された。地下水中のベンゼン濃 度が $1 \mathrm{mg} / \mathrm{L}$ を回ると気化効果は急激に低下し, 浄化対象とする帯水層中の地下水が栄養水に全 量置換する注水が行われた後に，微生物分解効 果によるベンゼンの減少傾向が確認された。ま た，注水バイオスパージング工法を適用したこ とによって, 従来のスパージング工法と比較し て，200日以上の早期浄化が達成されたことが 本解析により示された。そして，本結果から求 めた微生物分解項を有寸る予測解析手法は，本 実証試験結果にフィッティングしており，本工 法の浄化期間予測が可能であることを確認した。

(3) 注水スパージング井戸を利用した透水試験を実 施した結果，本サイトにおける自然浸透速度は， $8.33 \times 10^{-6} \mathrm{~m}^{3} / \mathrm{s} \quad(0.5 \mathrm{~L} / \mathrm{min})$ と算出された。これ に対し， $2.50 \times 10^{-3} \mathrm{~m}^{3} / \mathrm{s}(150 \mathrm{~L} / \mathrm{min})$ のスパージ ングを実施しながら同時に注水を行うことによ り，最大 $6.67 \times 10^{-5} \mathrm{~m}^{3} / \mathrm{s}(4 \mathrm{~L} / \mathrm{min})$ の栄養水を地 盤内に供給でき，自然浸透条件に対して8倍の 栄養水を供給できることが確認された。したが って，本工法は別途注水井戸を設ける必要がな く，速やかに微生物分解効果を高める栄養塩を 供給可能であることを証明した。

（4）今後適用していく注水バイオスパージング工法 に対して，本解析手法を用いてスパージング影 響半径や微生物分解速度に関する情報を蓄積し ていくことにより，個々の地盤条件に対応した 浄化設計の予測精度が向上することを期待して
いる.

\section{参考文献}

1) 環境省 : 環境白書, 平成 20 年度版, 2008 .

2) 石川洋二：油污染土のバイオレメディエーション, 環境科学会誌, Vol.20, pp.381-388, 2007.

3) 矢木修身：污染土壤のバイオレメディエーション技 術の現状と課題，用水と廃水，Vol.45，pp.19-26， 2003.

4) United States Environmental Protection Agency: How to Evaluate Alternative Cleanup Technologies for Underground Storage Tank Sites, Chapter VIII Biosparging, EPA 510-B-94-003, 1994.

5) US Army Corps of Engineers: Soil Vapor Extraction and Bioventing Engineer Manual, 2002.

6) US Army Corps of Engineers: Engineering and Design Insitu Air Sparging, 2008.

7) 社団法人 地盤工学会：続・土壤・地下水污染の調 査・予測・対策，pp.75-110，2008

8）河合達司，西願寺篤史，佐藤義幸，武藤彰：これか らの土壌・地下水污染技術 建物直下の VOC 污染の対 策技術 水平井を用いたエア/バイオスパージング技術, 環境浄化技術，9月号，pp.19-26，2005.

9) 河合達司，西願寺篤史，武藤彰：土壌 - 地下水污染 と最近の浄化技術 構造物直下の污染地下水の浄化技 術, Vol.33, pp.76-78, 2005

10) Mehlman, M. A.: Dangerous and cancer-causing properties of products and chemicals in the oil refining and petrochemical industry VIII Health effects of moter fuels: carcinogenicity of gasoline-scientific update, Environ. Res. Vol.59, pp.238-249, 1992.

11) Thomas, J. M. and Ward, C. H.: In situ biorestoration of organic contaminants in the subsurface, Environ. Sci. Thecnol., Vol.23, pp.760-766, 1989.

12) Willson, L. P. and Bouwer, E. J.: Biodegradation if aromatic compounds under mixed oxygen/denitrifying conditions: a rewiew, J. Ind. Microbiol. Biotechnol., Vol.18, pp.116-130, 1997.

13）田崎雅晴, 岡村和夫, 熊本進誠, 田澤龍三 : バイオ スパージングによるベンゼン污染土畩・地下水の浄 化，清水建設研究報告，第 74 号，pp.81-86， 2001.

14）加藤敏郎，伊藤公夫，高木敏彦：土壤 - 地下水浄化 技術 バイオスパージング法による油污染土壌浄化 浄 化指標としての微生物モニタリングの有用性，環境 浄化技術，9月号，pp.29-31，2006.

15) Weymann, D. F.: Biosparging used in aquifer remediation, Pollution Engineering, pp.36-41, 1995.

16) Strzempka, C. P., Woodhull, P. M., Vassar, T. M. and Jerger, D. E.: In-situ biosparging and soil vaper extraction for JP-4 contaminated soils and graudwater: A case study, In-situ and On-site Bioremediation 4, Vol.1, pp.245-250, 1997.

17) Muehlberger, E. W., Herris, K. and Hicks, P.: In situ Biosparging of a Large Scale Dissolved Petroleum Hydorocarbon Plume at a Southwest Lumber Mill, TAPPI Proceedings. International Environmental Conference \& Exhibit (Technical Association of the Pulp and Paper Industry), pp.95-101, 1997.

18) Raetz, R. M.: Accelerated BTEX and PNA removal rates 
using an automated bioprocessing system, In situ and OnSite bioremediation 4, Vol.5, pp.63-69, 1997.

19) United States Environmental Protection Agency: How to Evaluate Alternative Cleanup Technologies for Underground Storage Tank Sites, Chpter X In situ groundwater bioremediation, EPA 510-B-95-007, 1995.

20) Takahata, Y., Kasai, Y., Hoaki, T. and Watanabe, K.: Rapid intrinsic biodegradation of benzene, toluene, and xylenes at the boundary of a gasoline-contaminated plume under natural attenuation, Appl. Microbiol. Biotechnol., Vol.73, pp.713-722, 2006.

21）塚谷裕子, 馬場義輝, 志水信弘, 田中義人, 岩本真 二, 中村又善, 池浦太荘 : ボーリングコア試料中に おける他環芳香族炭化水素類濃度について, 福岡県 保険環境研究所年報，第 33 号，pp.104-107, 2006.

22) Breedveld, G. D. and Sparrevik, M.: Nutrient-limited biodegradation of PAH in various soil strata at a creosote contaminated site, Biodegradation, Vol.11, pp.391-399, 2000.

23）日本下水道協会：下水試験法（上巻）第 2 章 水質試 験, 第 29 節 全窒素 5. 銅・カドミウムカラム還元法, pp.188-189, 1997.

24）日本下水道協会：下水試験法（上巻）第 2 章 水質試 験, 第 30 節リン 1.りん酸イオン態りん（1）モリブ デン青吸光光度計, pp.192-193，1997.

25) 社団法人 地盤工学会 : 地盤調査の方法と解説, 第 6 章単孔を利用した透水試験, pp.377-393, 2004.

26) 江種伸之, 平田健正, 福浦清, 松下孝: 帯水層スパ ージングの現場実験，地下水・土䁃污染とその防止 対策に関する研究集会講演集, pp.147-148, 1998.

27) Mulder, G. J. and Vreeken, C.: Prediction and field testing radius of influence for biosparging, In Situ Bioremediation of Petroleum Hydrocarbon and Other Organic Compounds, pp.103-108, 1999.

28）小林弘明, 河合達司, 川端淳一, 佐藤義幸, 長澤知 紀 : エアースパージング工法による影響範囲に関す る考察, 第 58 回土木学会年次学術講演会, pp.613614, 2003.

29）小澤一喜，河合達司，川端淳一，中山等，佐藤義幸， 長澤知紀 : 実サイトでのエアースパージングの浄化 特性と影響範囲に関する研究, 地下水・土畩污染と その防止対策に関する研究集会講演集, pp.356-359, 2003.

30）平山彰彦，志賀剛：エアースパージング工法による 注入空気の分布特性, 第 40 回地盤工学研究発表会講 演集, pp.2647-2648, 2005.

31) 長藤哲夫, 今村聡, 日下部治, 平田健正 : 揮発性有 機塩素化合物の土壤ガス吸引法における浄化影響要 因に関する研究, 土木学会論文集, No.594/VII-7, pp.35-44, 1998.

32）日比義彦, 神野健二, 江種伸之, 川端淳一, 下村雅 則：現場透気試験時の不飽和土壤中の透気係数と影 響半径の算出手法について, 土木学会論文集 $\mathrm{C}$, Vol.62, No.2, pp.488-501, 2006.

33) 土質工学会 : 根切り工事と地下水一調査・設計から 施工まで, pp.79-85, 1991.

34) 今村聡, 未岡徹, 名倉克博 : 真空抽出工法による污 染浄化の予測手法に関する研究, 大成建設技術研究 所報，第 25 号，pp.187-194， 1992.

(2008. 12. 25 受付)

\title{
REMEDIATION OF BENZENE-CONTAMINATED AQUIFERS BY FLUSHING AND BIO-SPARGING METHOD
}

\author{
Hisashi KIRIYAMA, Yoh TAKAHATA, Masaya OISHI, \\ Motoshige ARIYAMA, Satoshi IMAMURA and Takeshi SATO
}

Biosparging method is an effective technology that remedies benzene-contaminated soils. This method enable to do physical removal of benzene by vaporization with supplying air into aquifer, also encourages biodegradation. However, since the efficient supply method of trofic salts has not exist yet, it has been difficult to do biodegradation continuously. The biosparging method which used soil flushing together that supplies trofic salts effectively under the ground has been developed. This original method was demonstrated its effectiveness through in-situ test, and discussed from the perspective of remediation rate and ability to supply air and trofic salts. As a result, proposed flushing and biosparging method was confirmed superiority compared with the conventional method. In addition, based on a result of the test, a designing method on well layout, sparging air rate and remediation term has also proposed. 